\title{
Effect of Residual Stress on Bending Fatigue Behavior of Inconel 718 Coated with WC-17Co
}

\author{
Ding Kunying ${ }^{1,2}, \quad$ Guo Yafei ${ }^{2}, \quad$ Zou Hui ${ }^{2}$ \\ ${ }^{1}$ Tianjin Key Laboratory for Civil Aircraft Airworthiness and Maintenance, Civil Aviation University of China, Tianjin 300300, China; ${ }^{2}$ College of \\ Science, Civil Aviation University of China, Tianjin 300300, China
}

\begin{abstract}
An Inconel 718 alloy was coated by WC-17Co using a high-velocity oxygen fuel (HVOF) thermal spray process. The residual stress of WC-17Co coating under different heat-treatment conditions was investigated. The effect of residual stress on bending fatigue life of the coated alloy was discussed. Results show that fatigue cracks are initiated at the WC-17Co coating and propagated to the alloy substrate. The compressive residual stress generated during HVOF process could restrict the initiation and propagation of cracks. The absolute value of the compressive residual stress in WC-17Co coating decreases after annealing treatment, resulting in a lower fatigue life of the coated specimens.
\end{abstract}

Key words: bending fatigue; WC-17Co; fatigue life; residual stress; crack

Hard chromium electroplating is used to improve the wear resistance of components of aero-engine, such as bearing house, rear hub, and turbine shaft ${ }^{[1]}$. However, chromium plating decreases the fatigue resistance of aircraft components because of the high tensile residual stresses in itself ${ }^{[2,3]}$. Consequently, researches have been carried out to find a suitable material to replace chromium plating. As an alternative of chromium plating, tungsten carbide cobalt (WC-Co) coating has been investigated for gas turbine engine components using a high velocity oxy-fuel (HVOF) thermal spray process ${ }^{[4-6]}$. Various tests have been examined ${ }^{[7]}$, especially fatigue tests. The axial fatigue testing (ASTM E466-96) has shown that the HVOF sprayed WC-Co coating generally less affects the fatigue life of a base metal in comparison with hard chromium electroplating. Some researchers claimed that this variance was attributed to the compressive residual stress in the WC-Co coating induced by the HVOF process ${ }^{[8,9]}$.

Differing from axial load, bending load is another force in aircraft components, particularly in gas turbine engine components such as compressor shafts and bearing holders.
However, few studies regarding bending fatigue behavior have been reported so far. In the present study, the bending fatigue characteristics of HVOF sprayed WC-17Co coated Inconel 718 alloy were evaluated, and the effects of varying residual stress on the bending fatigue life of coated alloys were discussed as well.

\section{Experiment}

The base material was an Inconel 718 alloy following the AMS 5663M standard. It is an anti-corrosion and heat-resistant alloy with the chemical composition (wt\%) of 50 55 Ni, 19.0 Cr, 19.0 Fe, 3.0 Mo, 5.1 ( Nb + Ta), and 0.9 Ti. Tensile tests were conducted according to ASTM E-8M standard procedure. The alloy has a yield strength of 1030 $\mathrm{MPa}$, a Young's modulus of $204 \mathrm{GPa}$, a Poisson's ratio of 0.3 , an ultimate tensile strength of $1256 \mathrm{MPa}$ and an elongation of $10 \%$. Specimens were prepared by a wire-cut machine from the rolled plate base material. And its rolling axis is parallel to the length of specimen. The fatigue specimen was a tapered and cantilever beam one. The typical dimensions of the specimen are shown in Fig.1. All

\footnotetext{
Received date: February 14,2016

Foundation item: Central University Basic Scientific Research Operation Cost Special Fund (ZXB2011A005)

Corresponding author: Ding Kunying, Ph. D., Lecturer, College of Science, Civil Aviation University of China, Tianjin 300300, P. R. China, Tel: 0086-20-24092074, E-mail:dingkunying@126.com

Copyright (C 2017, Northwest Institute for Nonferrous Metal Research. Published by Elsevier BV. All rights reserved.
} 
specimens failed at region $\mathrm{A}$ because of stress concentration.

The WC-17Co coating was deposited on the Inconel 718 alloy substrate using a Praxair powder 1343VM through the HVOF thermal-spray technique. A JP5000 HVOF system (TAFA, US) was used to spray the cermet coating. This system is based on a liquid fuel (kerosene of aviation grade) and oxygen gas. A gun mounted on a six-axis ABB 2400M robot was used to carry out the HVOF coating. The HVOF spraying parameters are presented in Table 1.

Prior to spraying, the substrate was degreased in ethanol and blasted by alumina grit with an average size of $0.25 \mathrm{~mm}$ under an air pressure of $0.6 \mathrm{MPa}$. After grit blasting, the average roughness value $\left(R_{\mathrm{a}}\right)$ of the substrate was $\sim 8 \mu \mathrm{m}$, as determined by optical profilometry. Both sides of the alloy were deposited with the WC-17Co coatings. Specimens with the coating thickness of $0.15 \mathrm{~mm}$ were prepared in this study, and the coatings had the average $R_{\mathrm{a}}$ of $\sim 6 \mu \mathrm{m}$. Before fatigue testing, the final polishing was carried out by the diamond abrasive band with the grain size of $30 \mu \mathrm{m}(3 \mathrm{M}$, US), thus leading to a reduction in $R_{\mathrm{a}}$ to $\sim 3 \mu \mathrm{m}$. A scanning electron microscope (SEM, QUANTA-200 FEI, Netherlands) was used to observe the morphology of coating. A D8 Advance X-ray diffraction (XRD) meter (Bruker, Germany, $\mathrm{Cu}-\mathrm{K} \alpha$ radiation, $40 \mathrm{kV}, 40 \mathrm{~mA}, 1 \% \mathrm{~min}$ scan rate) was employed to identify the present phases.

To analyze the effect of residual stress of the coatings on the properties of the specimen, two annealing processes $\left(150{ }^{\circ} \mathrm{C}\right.$ for $3 \mathrm{~h}$ and $300{ }^{\circ} \mathrm{C}$ for $\left.3 \mathrm{~h}\right)$ were carried out in a furnace. Then the specimens with different residual stresses were prepared. The residual stresses $\left(\sigma_{\mathrm{c}}\right)$ of coatings were evaluated by Almen strip and obtained from the Eq.(1) ${ }^{[10]}$

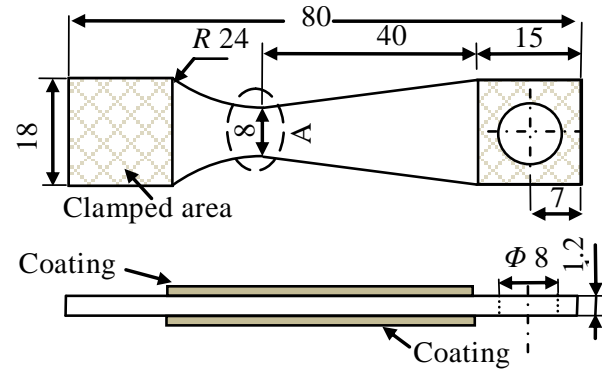

Fig. 1 Typical dimensions of the bending fatigue specimen

Table 1 HVOF coating spray parameters

\begin{tabular}{cc}
\hline Spray parameters & Values \\
\hline Oxygen flow rate $/ \mathrm{L} \cdot \mathrm{h}^{-1}$ & 53000 \\
Fuel flow rate $/ \mathrm{L} \cdot \mathrm{h}^{-1}$ & 23.5 \\
Powder flow rate $/ \mathrm{g} \cdot \mathrm{min}^{-1}$ & 65 \\
Spray distance $/ \mathrm{mm}$ & 380 \\
Gun movement $\mathrm{speed} / \mathrm{mm} \cdot \mathrm{s}^{-1}$ & 350 \\
Offset per pass $/ \mathrm{mm}$ & 4.0 \\
\hline
\end{tabular}

$$
\sigma_{\mathrm{c}}=-\frac{E_{\mathrm{s}} h_{\mathrm{s}}^{2}}{6\left(1-\nu_{\mathrm{s}}\right) h_{\mathrm{c}}}\left(K_{1}-K_{\mathrm{o}}\right) \delta
$$

where $E_{\mathrm{s}}, h_{\mathrm{s}}, v_{\mathrm{s}}$ is elastic modulu, thickness, and Poisson's ratio of the substrate alloy, respectively; $h_{\mathrm{c}}$ is the thickness of the coating; $K_{1}$ and $K_{0}$ are the curvature of the specimen before and after the coating deposition, respectively; and $\delta$ $=\left(1+4 \mathrm{e} t+6 \mathrm{e} t^{2}+4 \mathrm{e} t^{3}+\mathrm{e} 2 t^{4}\right) /(1+t)$ is the stress correction coefficient $\left(t=h_{\mathrm{c}} / h_{\mathrm{s}}\right)$. Curvature $(K)$ was obtained from Eq. (2) ${ }^{[11]}$

$$
K=\frac{1}{r}=\frac{2 \varepsilon}{L^{2}}
$$

where $r$ is the radius of curvature, $\varepsilon$ is the displacement value of the end of the specimen, and $L$ is the half length of the Almen strip (Fig.2).

The tapered beam fatigue specimen was loaded in a cantilever bending fixture using the RC-2000 vibration control system (Suzhou Testing Instrument Factory, China). The right end of the specimen was loaded with a vibration rod taking a repeated up-and-down displacement, and the left end of the specimen was clamped with a vise. The fatigue tests were conducted under bending conditions at $10 \mathrm{~Hz}$ with a minimum/maximum stress ratio of -1 . The deflection altitudes of vibration rod were applied for 6,7 and $8 \mathrm{~mm}$, corresponding to the strain values of $2.7 \%, 3.15 \%$, and $3.6 \%$, respectively. These strain values were recorded with the strain gauges attached to the stress concentrated region of the specimen. Four samples were tested at each deflection altitude. Specimen failures were defined by the complete fracture.

\section{Results and Discussion}

The cross sectional microstructure of the HVOF deposited WC-17Co coating is shown in Fig.3a. Using the backscattered electron detector in the SEM, different gray levels of the matrix and carbides could be seen in the image, indicating that the elements have an inhomogeneous distribution. Through the energy specturm analysis, the irregular particles are composed of element $\mathrm{W}$ and $\mathrm{C}$. The high brightness indicates these areas belong to the fringes

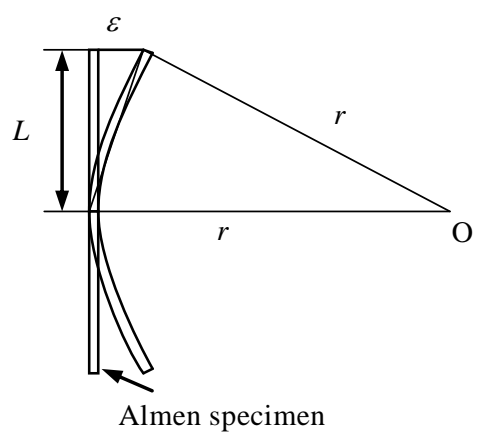

Fig. 2 Geometric relationships in the curvature system 

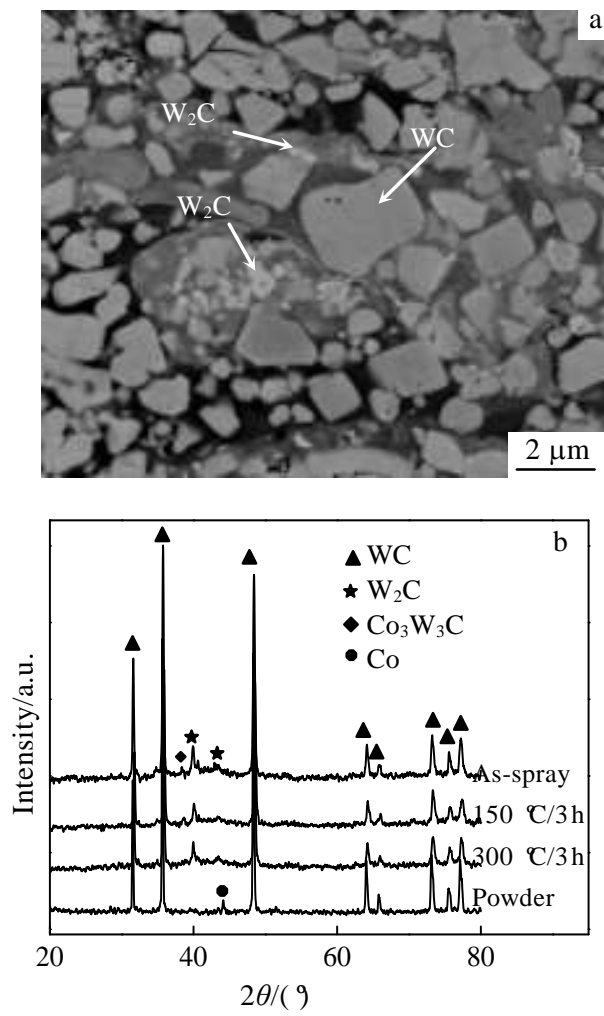

Fig. 3 SEM images of the WC-17Co coating (a) and XRD patterns of the powder, as-sprayed, and heat-treated WC-17Co coatings (b)

with high $\mathrm{W}$ content (element with the higher mean atomic number), which means these are $\mathrm{W}_{2} \mathrm{C}^{[12,13]}$. In addition, part of the WC is dissolved in the cobalt matrix and either an amorphous $\left(\mathrm{Co}_{3} \mathrm{~W}_{3} \mathrm{C}\right)$ or a nanocrystalline supersaturated solid cobalt solution is formed. The XRD patterns of the powder and coatings are shown in Fig. $3 \mathrm{~b}$. The $\mathrm{W}_{2} \mathrm{C}$ in the coating has the higher intensity of diffraction peak than $\mathrm{W}_{2} \mathrm{C}$ in the powder. This difference ascribes to the fact that the $\mathrm{W}_{2} \mathrm{C}$ is formed by decarburizing the WC during deposition. In addition, the XRD results indicate that the phase composition and content of the annealed coatings $\left(150{ }^{\circ} \mathrm{C}\right.$ for $3 \mathrm{~h}$ and $300{ }^{\circ} \mathrm{C}$ for $3 \mathrm{~h}$ ) has no evident variations compared with that of the as-sprayed coatings.

The average residual stress of the WC-17Co coating after annealing with different temperatures is shown in Fig.4. The results show that the as-sprayed coating has the highest compressive residual stress of approximate $-86.8 \mathrm{MPa}$. The residual stress in the coating is about $-59.7 \mathrm{MPa}$ after annealing at $150{ }^{\circ} \mathrm{C}$ for $3 \mathrm{~h}$, and then declines to $-22.3 \mathrm{MPa}$ after annealing at $300{ }^{\circ} \mathrm{C}$ for $3 \mathrm{~h}$.

The bending fatigue behaviors of three specimens (as-spayed, annealed at $150{ }^{\circ} \mathrm{C}$ for $3 \mathrm{~h}$, annealed at $300{ }^{\circ} \mathrm{C}$ for $3 \mathrm{~h}$ ) were investigated at room temperature. Fig. 5 shows the number of cycles to failure corresponding to the

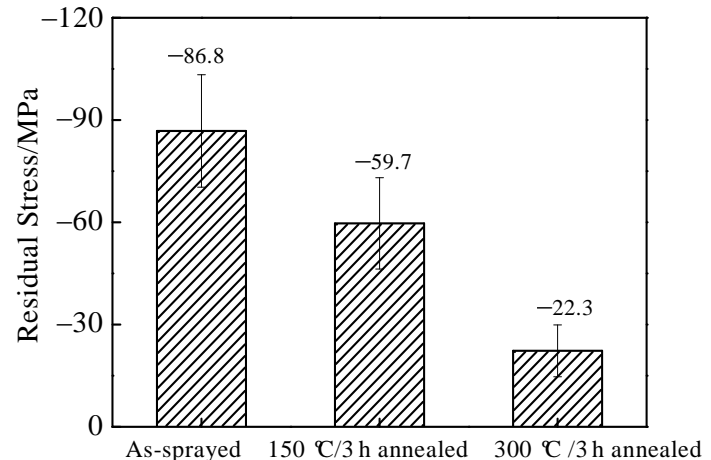

Fig. 4 Residual stress of WC-17Co coating after different annealing processes

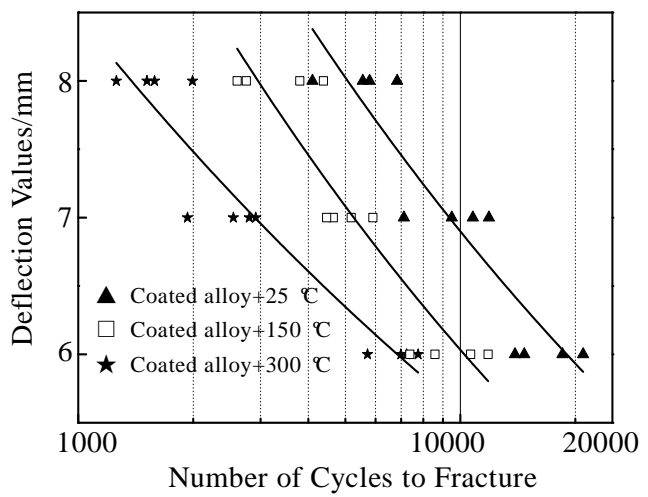

Fig. 5 Curves of the fatigue life of WC-17Co-coated Inconel 718 alloy versus bending deflection value in different conditions

different deflection values in the specimens. Obviously, the increased deflection value clearly decreases the lives of the specimens. The experimental data indicate that the annealed specimens have shorter fatigue lives. For example, under the same deflection value of $6 \mathrm{~mm}$, the as-sprayed specimens failed at around $1.7 \times 10^{5}$ cycles, while specimens annealed at $150{ }^{\circ} \mathrm{C}$ for $3 \mathrm{~h}$ and specimens annealed at $300{ }^{\circ} \mathrm{C}$ for $3 \mathrm{~h}$ failed at around $9.6 \times 10^{4}$ cycles and around $6.9 \times 10^{4}$ cycles, respectively. Hence, the bending fatigue lives of the specimens are affected by the heat-treatment. Generally, the fatigue lives of the as-sprayed specimens decreases by $\sim 40 \%$ after annealed at $150{ }^{\circ} \mathrm{C}$, and by $60 \%$ after annealed at $300{ }^{\circ} \mathrm{C}$.

Analyzing the crack extending style is necessary to explain the fatigue life variance of different kinds of specimens. Thereby the as-sprayed fatigue specimen loaded with $6 \mathrm{~mm}$ of deflection was split and polished after 50000 cycles. Fig.6a shows its cross section morphology. It illustrates that a fatigue crack nucleated on the coating surface and subsequently propagates to the interface. Another fatigue specimen was annealed firstly at $300{ }^{\circ} \mathrm{C}$ for 


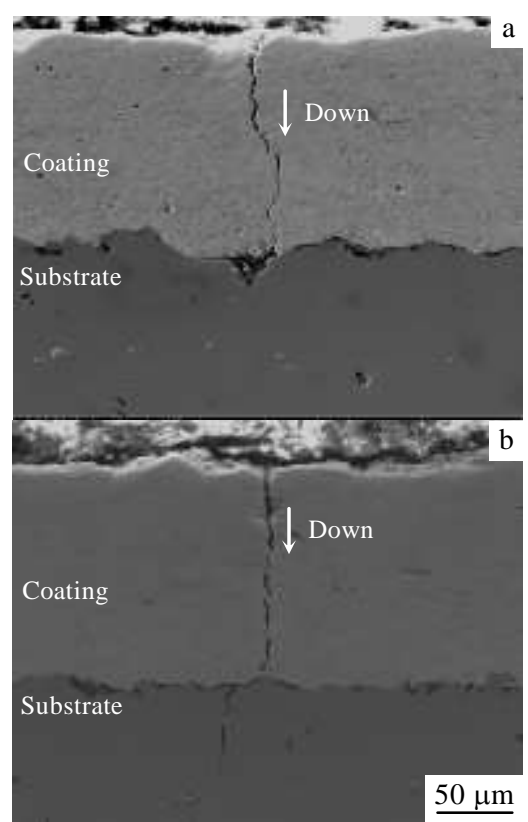

Fig. 6 SEM images of the cross section of the as-sprayed fatigue specimen (a) and the fatigue specimen annealed at $300{ }^{\circ} \mathrm{C}$ for $3 \mathrm{~h}(\mathrm{~b})$

$3 \mathrm{~h}$, then also loaded with $6 \mathrm{~mm}$ of deflection and split after 50000 cycles. Fig.6b shows the cross section morphology of the later specimen. The fatigue cracks are also initiated on the coating surface. However, in the present case, the fatigue crack exhibites a longer propagating path than that of the former case.

For the above specimens, fatigue cracks are initiated and then propagated in the coating, indicating that the fatigue lives of the specimens are affected by the WC-17Co coating. No evident difference is visible in phase composition between the two annealed coatings and as-sprayed coatings. (Fig.3b). Factors other than phase transformation affect the fatigue life of the coated specimens. Several researches have reported that the residual stress in the coating plays an important role in fatigue life $\mathrm{e}^{[14]}$. Residual stress generated in thermally sprayed coatings has been well researched by various workers. It has been proved that the residual stresses are generated from three main sources: qunching stress, thermal stress and peening stress. During HVOF processes, low spray temperatures and high impact velocity particles were used, and significant peening stresses $\operatorname{arose}^{[15]}$. Therefore, the residual stress in HVOF coatings usually exhibit compressive nature due to significant peening stresses.

For HVOF thermal sprayed WC-17Co coatings, the compressive residual stress is induced by a plastic deformation of predeposited particles, which is caused by the impingement of the partially molten particles at high velocity $^{[16]}$. This residual stress delays fatigue crack propagation during the cycling load. After annealing, the deformed particles have a possibility to generate a recovery, inducing a relaxation of compressive residual stress. In the present paper, the average absolute value of compressive residual stress decreases by $\sim 40 \%$ for annealed specimens at $150{ }^{\circ} \mathrm{C}$ for $3 \mathrm{~h}$ and decreases by $\sim 70 \%$ for annealed specimens at $300{ }^{\circ} \mathrm{C}$ for $3 \mathrm{~h}$, in comparison with the as-sprayed ones. For this reason, the cycle number, when the crack is initiated and propagated in the $\mathrm{WC}-17 \mathrm{Co}$ coating, decreases with the increasing annealing temperature, and thus the fatigue life is reduced.

\section{Conclusions}

1) XRD peaks corresponding to $\mathrm{W}_{2} \mathrm{C}$ and $\mathrm{Co}_{3} \mathrm{~W}_{3} \mathrm{C}$ are detected on the deposited coating; the phase composition and content of the as-sprayed coating has no evident variations between annealing at $150{ }^{\circ} \mathrm{C}$ and annealing at $300{ }^{\circ} \mathrm{C}$.

2) The compressive residual stress is generated in the coating during the spraying process. After annealed at $150{ }^{\circ} \mathrm{C}$ or $300{ }^{\circ} \mathrm{C}$, the absolute value of average compressive residual stress decreases.

3) At the same bending deflection, the fatigue life of the coated specimen annealed at $150{ }^{\circ} \mathrm{C}$ is $\sim 40 \%$ is shorter than that of the as-sprayed condition. Moreover, the decrease in the fatigue life is up to $\sim 60 \%$ when annealed at $300{ }^{\circ} \mathrm{C}$.

4) The fatigue cracks are initiated on the surface of coating and then propagated to the substrate. It can be concluded that the compressive residual stress of the fatigue specimen is released partly during the annealing process, resulting in a decrease of fatigue life.

\section{References}

1 Camón A F, Blas J G, Hoyo J C et al. Journal of Thermal Spray Technology[J], 2011, 20(6): 1292

2 Nascimento M P, Souza R C, Miguel I M et al. Surface \& Coatings Technology[J], 2001,138: 113

3 Hou G L, Zhou H D, An Y L et al. Rare Metal Materials and Engineering[J], 2012, 41 (S1): 388 (in Chinese)

4 Chivavibul P, Watanabe M, Kuroda S et al. Journal of Thermal Spray Technology[J], 2010, 19(1-2): 81

5 Hasan M, Stokes J, Looney L et al. Journal of Material Engineering Perform[J], 2009, 18(1): 66

6 Hazra S, Sabiruddin K, Bandyopadhyay P P. Surface Engineering [J], 2012, 28(1): 37

7 Voorwald H J C, Souza R C, Pigatin W L et al. Surface \& Coatings Technology[J], 2005,190: 155

8 Costa M Y P, Venditti M L R, Voorwald H J C et al. Materials Science and Engineering A[J], 2009, 507: 29

9 Camargo J A M, Voorwald H J C, Costa M Y P. Surface \& Coatings Technology[J], 2007, 201: 9448

10 Wang T G, Zhao S S, Hua W G et al. Materials Science and Engineering $A[\mathrm{~J}], 2010,527: 454$ 
11 Liao H, Vaslin P, Yang Y et al. Journal of Thermal Spray Technology[J], 1997, 6(2): 235

12 Ji S C, Li Z X, Du J H et al. Rare Metal Materials and Engineering[J], 2012, 41(11): 2005 (in Chinese)

13 Guilemany J M, Paco J M, Nutting J et al. Metallurgical and Materials Transactions A[J], 1999, 30: 1913
14 Wasekar N, Ravi N, Babu P S et al. Metallurgical and Materials Transactions A[J], 2010, 41: 255

15 Santana Y Y, Renault P O, Sebastiani M et al. Surface \& Coatings Technology[J], 2008, 202: 4560

16 Denzer R, Svendsen B. Journal of Thermal Spray Technology[J], 2012, 21(1): 96

\title{
残余应力对涂覆 WC-17Co 涂层的 Ni718 合金弯曲疲劳寿命的影响
}

\author{
丁坤英 ${ }^{1,2}$, 郭亚飞 ${ }^{2}$, 邹 慧 $^{2}$ \\ (1. 中国民航大学 天津市民用航空器适航与维修重点实验室, 天津 300300) \\ (2. 中国民航大学 理学院, 天津 300300)
}

\begin{abstract}
摘 要: 利用超音速火焰喷涂技术在Ni718合金表面制备WC-17Co涂层, 对喷涂后的试样进行 $150{ }^{\circ} \mathrm{C}, 3 \mathrm{~h}$ 和 $300{ }^{\circ} \mathrm{C}, 3 \mathrm{~h}$ 保温热处理, 利 用Almen试片曲率法计算不同热处理条件下涂层中的残余应力, 用反复弯曲试验测试试样的疲劳寿命, 分析残余应力对试样疲劳寿命的 影响。结果表明, 在疲劳循环过程中, 裂纹在涂层中萌生并向涂层/基体界面处扩展, 最后扩展至基体内部形成最终断裂。涂层中的残 余压应力能够抑制疲劳裂纹的产生和扩展。经过保温处理后涂层中的残余压应力降低, 导致试样的疲劳寿命随热处理的温度上升而下降。 关键词: 弯曲疲劳; WC-17Co; 疲劳寿命; 残余应力; 裂纹
\end{abstract}

